\title{
Spotlight i: Official Development Assistance in 2020 - debated, disrupted and relevant, still.
}

\author{
Ida Mc Donnell, OECD
}

Official development assistance (ODA) is defined by the OECD Development Assistance Committee (DAC) as official government resources that promote and specifically target the economic development and welfare of developing countries under concessional financial terms ${ }^{16}$.

In 2018, the 29 member countries of the DAC provided 153.3 billion USD as official development assistance, accounting for $0.30 \%$ of gross national income (grant equivalent measure) ${ }^{17}$. ODA flows are significantly higher now than at the turn of the $21^{\text {st }}$ century. In 2000 , total ODA for DAC countries as a percentage of GNI was $0.22 \%$. However, growth has levelled out since 2008, averaging $0.30 \%$ of DAC countries' GNI over the period. As a whole, global ODA efforts fail to match the collective ambition of the 2030 Agenda for Sustainable Development or the development finance commitments and ambitions, including the UN target of $0.7 \%$ ODA/GNI, set out in the Addis Ababa Action Agenda.

\section{Box 1: Top five ODA providers in 2018: volume and share of GNI}

Top five by volume: United States (34.2 billion USD), Germany (25 billion USD), the United Kingdom (19.4 billion USD), Japan (14.2 billion USD) and France (12.1 billion USD).

Just five DAC members met or surpassed the UN target for a ratio of ODA to GNI of $0.7 \%$ : Denmark (0.72\%), Luxembourg (0.98\%), Norway $(0.94 \%)$, Sweden $(1.04 \%)$ and the United Kingdom $(0.70 \%)$.

16 All ODA-related definitions are available here: http://www.oecd.org/dac/financing-sustainable-development/development-finance-standards/officialdevelopmentassistancedefinitionandcoverage.htm (15.04.2020). OECD 2020. 
The DAC adopted ODA as the "gold standard" of so-called foreign aid in 1969. This statistical measure has provided transparency to improve development cooperation policies while also enabling countries to set targets for increasing their development cooperation effort (e.g. $0.7 \%$ ODA/GNI target, $0.15-0.20 \%$ GNI for least developed countries, and input targets in some sectors). Still, the definition's broad focus on promoting economic development and welfare means it is open to interpretation. There has always been debate about the appropriateness and credibility of the ODA concept ${ }^{18}$. These discussions tend to be highly technical and highly political, as illustrated in 2017 when the DAC could not reach a consensus on the rules for counting ODA contributions in private sector instruments ${ }^{19}$ or debt relief under the new grant equivalent methodology.

Fifty years since its creation, the strategic role and added value of ODA continues to be debated. ODA priorities are shaped by shifting geo-politics, economic and fiscal constraints in provider countries as well as progress and challenges to international development. In some cases, this translates into demands to adjust ODA rules, which could boost (or undermine) the integrity of this gold standard. For example, the 2015 surge in the flows of refugees into many DAC member countries led them to clarify the rules for in-donor refugee costs two years later ${ }^{20}$. Similarly, important boundaries have been set on military aid or cultural programmes ${ }^{21}$. Typically, updates to the DAC statistical reporting directives promote greater transparency and accountability as well as legitimacy for specific issues. The ODA policy markers on gender equality and women's economic empowerment, biodiversity targets and climate change provide crucial comparative data and an impetus for DAC members to deliver on these priorities. The latest marker for 'The inclusion and empowerment of persons with disabilities' responds to the pledge in the 2030 Agenda to leave no one behind ${ }^{22}$.

At recent ministerial level meetings of the DAC (e.g. in 2014 and 2017), members emphasised the critical financing role of ODA in countries most in need (such as least developed countries, small island developing states, fragile contexts), which tend to struggle to attract other external investments, especially private ones. In least developed countries, ODA represents $60 \%$ of

19 OECD 2018a; OECD 2018b.

20 OECD 2017.

21 For more information, see OECD: Official development assistance-definition and coverage. 
external finance compared to $13 \%$ for non-LDCs ${ }^{23}$. Yet, the share of ODA to LDCs dropped from $32.5 \%$ of the total ODA in 2010 to $29 \%$ in $2017^{24}$. New ODA rules, agreed in 2017, give more ODA credit for lending to poorer countries, reflecting the greater risk providers take in these contexts while serving, potentially, as an incentive for them to invest more. The extent to which these rules will bear fruit is unclear, but there are promising signs: final OECD data for 2018 show that the total ODA from DAC countries to least developed countries was 45.9 billion USD, an increase of $3 \%$ in real terms.

While the new rules strive to create fairer global distribution of the total ODA between countries, the DAC also stresses that ODA plays a critical and evolving role in middle-income countries and countries transitioning ${ }^{25}$ through income levels, which face specific challenges and continue to be eligible to receive ODA $^{26}$.

\section{Adapting to $21^{\text {st }}$ century challenges}

A key question pre-occupying DAC members is how to ensure development cooperation is most effective in helping countries deliver the SDGs for all and reaching the furthest behind first. The answer depends on its capacity to take on the 21st century's complex development challenges, such as inequality, forced displacement, the impacts of climate change or protecting international public goods. It also depends on the catalytic role that development cooperation plays in the evolving international landscape, where the diversity of public and private actors and financial instruments is growing, while ODA budgets appear to be plateauing. Providers of development cooperation will need to team up with other actors more effectively in this complex global development system ${ }^{27}$.

ODA alone cannot provide the trillions needed to fund the 2030 Agenda, but it helps in a unique way, thanks to its concessional nature and specific focus. DAC members need, however, to shift their focus on assessing performance according to the size of budgets; what matters more is maximising and showing the unique contribution development cooperation policies, knowledge, ideas

\section{OECD 2019.}

24 Ibid.

25 For more information, see contribution by Cecilia Piemonte and Olivier Cattaneo on Transition Finance in this publication.

26 The threshold for high-income countries graduating from the DAC List of ODA recipients is a GNI per capita higher than 12,235 USD for three consecutive years. For additional information about graduation from the DAC List of ODA Recipients, see OECD: History of DAC Lists of aid recipient countries and also the DAC HLM Communiqué of 2017.

27 See Ingram/Lord 2019. 
and finance (ODA and beyond) actually make to progress in well-being, resilience and sustainability in developing countries.

Today's narratives and priorities for development cooperation tend to emphasise national, bilateral interests (including commercial) over other principles for effective development cooperation ${ }^{28}$, and multilateral cooperation for peace, prosperity and the planet. Yet, when countries signed up to the SDGs, they supported a shift in thinking about the universal nature of sustainable development: ideas of charity, of "us" and "them" and "developed" and "developing", which have underpinned official development assistance since the 1960s, are outdated in the face of today's problems and solutions that are rarely contained or found within national borders. Development cooperation, including the mix of official financing for development, needs a fresh narrative that explains to a wider public what it is, how it operates and why it is needed. The 2019 OECD Development Cooperation Report "A Fairer, Greener, Safer Tomorrow" 29 proposes a call to action to bring the full capacities and resources of the development system to bear on the immense challenges of our time (see Figure 1).

28 For more information, see: http://effectivecooperation.org/about/principles/ (15.04.2020).

29 OECD 2019b. 
Figure 1: A call for change of course in development cooperation

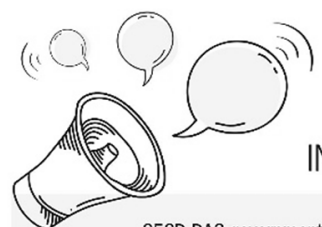

\section{A CALL FOR A CHANGE OF COURSE} IN DEVELOPMENT CO-OPERATION

OECD DAC governments and their development agencies need to show through words, actions and investments that development co-operation is fit to take on $21^{\text {st }}$ century challenges and open to working with diverse actors for long-term development results.

THE REPORT CALLS FORA CHANGE OF COURSE AND ACTION ON THREE FRONTS.
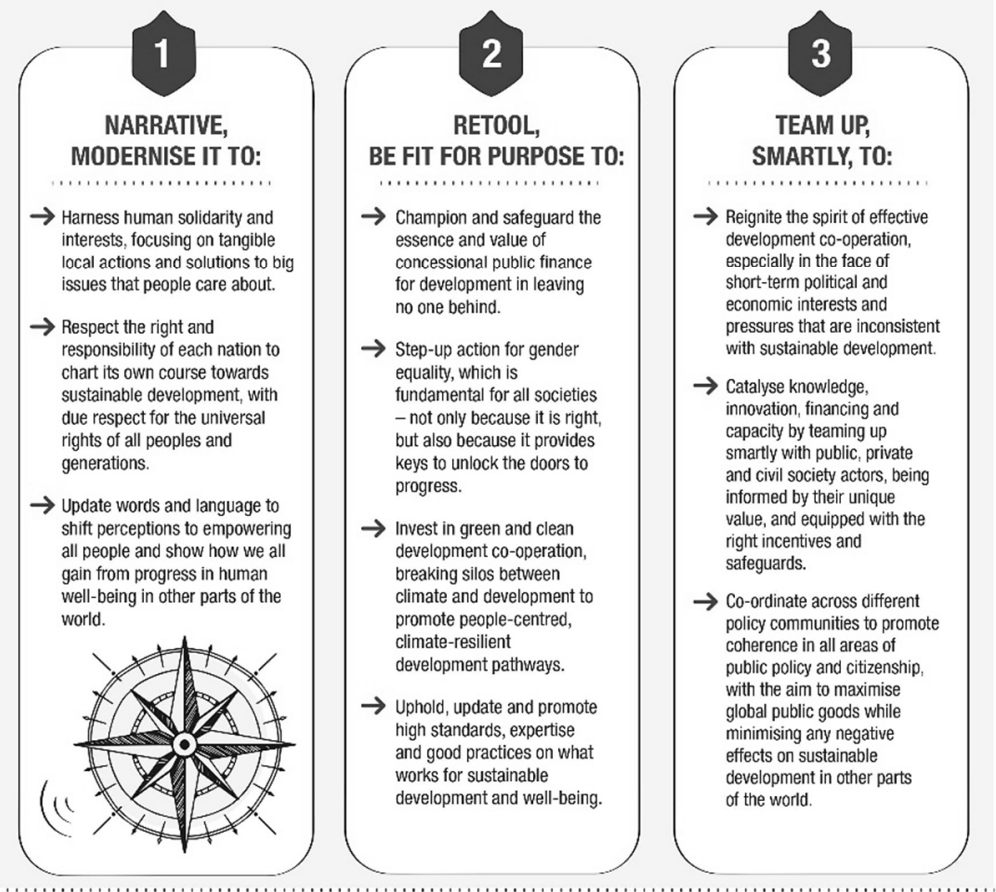
